\title{
Authoritarian Institutions and Regime Survival: Transitions to Democracy and Subsequent Autocracies*
}

\author{
Joseph Wright \\ Abel Escribà-Folch
}

October 2010

\begin{abstract}
This paper examines how authoritarian parties and legislatures affect regime survival. We argue that while authoritarian legislatures increase the stability of dictators, political parties, even when devised to quell internal threats, can destabilise dictators. The main hypothesis argues that authoritarian parties can influence the distribution of power in a subsequent democracy by helping to protect the interests of authoritarian elites in new democracies. Thus these institutions increase the likelihood of democratization. Accounting for simultaneity bias, we model both transitions to democracy and transitions to a subsequent authoritarian regime using a data set of 200 authoritarian regimes in 108 countries from 1946 to 2002 . We find that authoritarian legislatures stabilise dictators by decreasing the probability of being replaced by a subsequent dictator. Authoritarian parties, however, do little to deter authoritarian threats but increase the likelihood of democratization.
\end{abstract}


Recently, scholars have begun to look systematically at authoritarian political institutions such as parties, legislatures, and elections. ${ }^{1}$ In this article, we explore how authoritarian parties and legislatures affect the survival of authoritarian regimes, distinguishing between two types of authoritarian failure: transition to a subsequent dictatorship and democratization. Further, we analyze legislatures and parties as distinct institutions that can affect authoritarian survival through different mechanisms. Importantly, we examine how these institutions affect authoritarian elite under both dictatorship and democracy.

Legislative institutions in authoritarian regimes can help sustain the dictator in power by making the dictator's promises - to both potential authoritarian rivals and wouldbe democrats - more credible. Accordingly, these institutions might preserve authoritarian power by decreasing both the likelihood of being replaced by a rival dictator and the chances of democratization. However, authoritarian parties may also affect the likelihood of democracy by influencing the distribution of power in a subsequent democracy. Relative to other types of regimes, party elites in dominant party regimes are more likely to participate in and win competitive post-authoritarian elections, preserving some modicum of power for themselves in a new democracy. In military regimes, elites use parties to guarantee their corporate interests are protected after a transition to democracy. Because authoritarian party systems can guarantee at least some of the interests of the outgoing elites, these institutions make a transition to democracy more likely, all else equal. To test these expectations about how legislative institutions and party systems influence survival, we model the effect of legislatures and parties on transitions to both a subsequent dictatorship and to a new democracy. 
The argument that authoritarian parties can help protect the interests of authoritarian elites in a subsequent democracy via an "exit guarantee" builds on recent research on comparative democratization. ${ }^{2}$ Incorporating the insights of the Meltzer and Richard model, this literature posits that structural characteristics of the economy, such as income inequality or asset mobility, limit the ability of the enfranchised poor to tax the rich in a democracy. ${ }^{3}$ When relatively high equality or dependence on mobile assets constrains taxation of the rich in a democracy, elite interests are better protected and democratization is more likely. The present paper expands on this notion by suggesting that party legacies can play a similar role of protecting elite interests in a subsequent democracy. The central interest of authoritarian elites may not simply be to protect themselves from taxation under democracy. Political institutions are thus relevant when considering the wide range of interests outgoing authoritarian elites may like to protect.

There are numerous cases of democratization in countries with both high income inequality and low asset mobility - for example, the transitions from military rule in many Central American countries. To understand democratization in these countries, we might consider that military elites may not always view guarantees of modest taxation as the necessary condition for ceding power to democrats. Rather, their chief concern may be protecting the military's corporate interests, such as securing ample military budgets or immunity from human rights prosecution. ${ }^{4}$ Insofar as authoritarian parties can influence the distribution of power in a post-authoritarian democracy to help protect these interests, these institutions should make democratization more likely.

By considering the role of parties in protecting authoritarian elites' interests, we expand the purview of authoritarian elites beyond simply the "rich" to incorporate authoritarian regimes with diverse political coalitions of support where, for example, elites 
represent ethnic majorities (UMNO in Malaysia) or labor (PRI in Mexico for many decades). In doing so, we move beyond the redistributive focus of the models in Acemoglu and Robinson and Boix without losing its key implication: authoritarian elites are more likely to transition to democracy when their interests are better protected in a new democracy. ${ }^{5}$ In this formulation, "interests" no longer need be constrained to "low taxes," but can encompass a diverse array of concerns, from military immunity (Guatemala) to the preservation of ethnic group priorities (Malaysia).

In the first section, we discuss how authoritarian parties and legislatures influence the two distinct types of authoritarian failure: transition to a subsequent dictatorships and democratization. We outline hypotheses that link these institutions to autocratic survival. We then discuss the types of dictatorships that are likely to have legislative institutions and political parties that are sufficiently strong to exert influence over the distribution of power in a new democracy. In the third section, we discuss the data and methods used to test the main hypotheses, and then present the results of simultaneous equation duration models. We also test one implication of the "exit guarantee" argument by examining how institutions affect the post-exit fate of the dictators themselves. We conclude with a brief discussion of the implications of our findings for future research.

\section{Parties, legislatures, and authoritarian survival}

In this section, we discuss the distinct channels through which authoritarian parties and legislatures influence the survival of dictators. In doing so, we distinguish how these institutions affect two types of authoritarian regime failure: (1) being replaced by a rival dictator and (2) democratization. 
Many influential models of democratization articulate logics of strategic interaction between two (or sometimes three) actors - typically circumscribed as the regime/dictator/elite/rich and the opposition/citizens/insurgents/poor. ${ }^{6}$ These models help us specify how various factors affect the payoffs to the actors under different scenarios in a game of democratization. For example, they can help distinguish how particular factors (in our case political institutions) affect the cost of democratization for the dictator and the payoffs to the opposition under dictatorship. Understanding how political institutions affect payoffs to different players under both dictatorship and democracy provides insight into their effect on the stability of authoritarian regimes.

One view of authoritarian legislatures argues that these institutions neutralise threats from groups outside the regime by incorporating them into the governing structure of the regime itself. $^{7}$ One way of mapping this intuition onto models of democratization is to suggest that legislative institutions can increase the probability that the dictator does not renege on promises made to those who can credibly threaten to destabilise the regime. In Acemoglu and Robinson's model, the promise of redistribution is not credible because the dictator can renege in future periods. ${ }^{8}$ The view of legislatures as broadening the basis of regime support is consistent with the logic that these institutions provide a credible guarantee that the regime will not renege on promises to forgo predation, permit policy concessions to the opposition, or redistribute away from the elite in the future. In this scenario, these institutions raise the cost (to the dictator) of reneging and therefore increase the payoffs regime opponents receive under dictatorship. So to the extent that legislative institutions in dictatorships lend credibility to the dictator's promises, they should reduce the likelihood of democratization. If the regime opponents are not interested in democratization but simply want to replace the incumbent dictator with a new dictatorship, ${ }^{9}$ 
and if legislative institutions can increase the credibility of promises made to these opponents, then the same logic suggests that legislative institutions should decrease the likelihood of transition to a subsequent authoritarian regime. Whether the opponents are would-be democrats or not, the effect of legislative institutions should be the same. These arguments focus on the payoffs to (potential) regime opponents under dictatorship but say nothing about the payoffs to either actor under democracy.

The prevailing view of authoritarian parties also suggests that they are a stabilizing factor in dictatorships for a number of reasons: they can increase the credibility of promises made to party insiders, provide a buffer against military power, help coopt relatively powerful opponents, or help the dictator split moderate opponents from radical opponents. One avenue through which parties might stabilise authoritarian rule is to increase the credibility of the dictator's promise to groups that can threaten to replace the dictator. These would-be opponents may be party insiders, as Magaloni suggests, or powerful groups outside the regime, as Gandhi and Przeworski posit. ${ }^{10}$ This should decrease the likelihood the dictator is replaced by a subsequent authoritarian ruler. Similar to logic for stabilizing legislative institutions, these arguments suggest that parties increase the payoffs to regime opponents when they choose not to mobilise against the dictator. Second, parties might increase the costs of mobilizing against a dictator, perhaps by countering military threats to the dictator or by splitting the moderate opposition from the extremist opposition by raising the moderate opposition's cost of joining the radical opposition in conflict against the dictator. ${ }^{11}$ These arguments focus on the payoffs to potential regime opponent from pursuing a strategy that includes conflict with the dictator. To the extent that party insiders, the military, powerful outside groups, or moderate opponents press for democratic rule, these arguments suggest that parties should decrease the likelihood of democratization as 
well. Again, these theories say nothing about how institutions might affect the payoffs of various actors under democracy.

An alternative view of parties, derived from the standard theories concerning the origins of parties in democracies, is that they reduce collective action costs for party members, which in an authoritarian context might include potential regime opponents. ${ }^{12}$ In Acemoglu and Robinson's account of democratization, the necessary starting point is a period when there exist sufficiently low collective action costs that those demanding democracy can successfully mobilise. They suggest economic crisis as one of these fleeting moments when the poor can overcome their collective action costs and credibly threaten the dictator with a fight. If parties, even authoritarian support parties, lower the collective action costs of would-be regime opponents (who at various time may be nominal regime allies), then parties may decrease the cost of fighting against a dictator, and therefore increase the likelihood of both democratization and transition to a subsequent dictatorship. ${ }^{13}$ Even in dominant party regimes that are typically thought to be the most resilient, successful challengers frequently organise themselves first within the structure of the dominant party and then defect. For example, leaders of challengers parties in Mexico (Cuauhtémoc Cárdenas’ PRD), Kenya (Kibaki’s NAK and Odinga's LDP which formed the Rainbow Coalition in 2002), and Malaysia (Anwar's PRK) all organised support while members of the dominant party before defecting and establishing opposition parties.

This argument about parties and collective action costs for regime opponents highlights one way in which parties and legislatures may differ: a dictator may more easily observe the activities of a legislature than the activities of political parties simply because legislatures typically meet in a central location at specific times. Party activities, on the other hand, can take place throughout the country and can occur without the full knowledge 
of the dictator. Thus because a dictator has less ability to monitor all party activities, they should be more likely to be the institution where potential opponents can incubate collective action. This logic says nothing about whether regime opponents seek democratic change or simply want to replace the current dictator with another; thus the most general implication is that parties can increase the likelihood of either type of transition.

Another argument for why parties may destabilise focuses on a second avenue through which authoritarian parties can affect the interaction between dictators and their opponents: authoritarian parties might influence the distribution of power in a subsequent democracy, and in doing so lower the cost of democratization for incumbent authoritarian elites. In dominant party regimes, such as Mexico's PRI, the incumbent party often has deep distributional networks and large-scale mass support, which should translate into more effective voter mobilization and a larger claim on power in a new democracy. Because of the electoral success of former authoritarian parties in new democracies, the interests of these elites are better protected after a transition than if the former authoritarian elites had no party structure. ${ }^{14}$ This logic highlights another potential difference between parties and legislatures: parties are the actual organizations that can potentially win power even after democratization.

Further, many military regimes strike bargains with civilian elites during a transition in an attempt to guarantee their interests with political parties that are likely to do well in a subsequent democratic election. ${ }^{15}$ The institutionalization of an authoritarian party system under military rule can make these bargains more credible by increasing the chances an ally of the military will be elected as president in the subsequent election, particularly if the military uses the authoritarian party to influence the selection of electoral rules in an ensuing democracy. Thus, parties may increase the likelihood of "exit guarantees" for the 
military and their allies. ${ }^{16}$ If authoritarian parties can help protect the interests of authoritarian elites in a new democracy, then they should increase the likelihood of democratization. The actual organizations capable of possibly protecting elite power are parties, not simply the existence of a legislature during the authoritarian period. This logic of exit guarantees has implications for democratization, but says nothing about transitions to subsequent authoritarian regimes.

To summarise briefly, because authoritarian legislatures increase the credibility of bargains between the dictator and potential threats, legislatures should decrease the likelihood of both a transition to a subsequent dictatorship and a transition to democracy. If the prevailing view of authoritarian parties is correct, these too should decrease the probability of transition to a subsequent dictatorship and perhaps transition to democracy as well. An alternative hypothesis regarding parties argues that authoritarian parties may actually be destabilizing as they can both increase the likelihood of democratization by helping protect the interests of the incumbent elites in a new democracy and increase the likelihood of being deposed by a rival dictator by reducing the collective action costs of those organizing to overthrow the incumbent dictator. The discussion so far, however, presumes that parties and legislatures are sufficiently strong to alter the incentives of the various actors involved. For example, the arguments rely upon the assumptions that legislatures credibly constrain the dictator in some fashion and that parties can influence the distribution of power after a transition to democracy. In the next section, we discuss when these assumptions are more or less likely to be true by examining these institutions in different types of authoritarian regimes.

This discussion suggests a number of testable hypotheses: 
Hypothesis 1: Legislatures decrease the likelihood of an authoritarian regime being replaced by a subsequent (rival) dictatorship.

Hypothesis 2: Legislatures decrease the likelihood of democratization

Hypothesis 3: Parties increase the likelihood of an authoritarian regime being replaced by a subsequent (rival) dictatorship.

Hypothesis 4: Parties increase the likelihood of democratization.

There is a further implication suggested by the argument that authoritarian parties increase the likelihood of democratization by protecting the interests of the outgoing authoritarian elites. Parties should protect dictators themselves after leaving power. Thus dictators exiting from power in regimes that have parties should be better off than dictators in regimes with no (or fewer) parties.

Hypothesis 5: Parties should reduce the likelihood of exile, arrest or assassination (relative to staying in the country unharmed) for exiting dictators.

\section{Parties and legislatures in different types of authoritarian regimes}

While thus far we have discussed the effects of party and legislative institutions, much of the literature on authoritarianism distinguishes among different types of regimes, such as personalist (or sultantistic) and military regimes. ${ }^{17}$ These regime types have important consequences for how elites survive in power. ${ }^{18}$ In addition to being important controls, the fact that authoritarianism has many faces that can be usefully circumscribed by regime type may provide insight into the relevant scope of the main hypotheses. Thus far we have 
assumed that legislatures and parties are sufficiently strong to (1) credibly constrain the dictator, in the case of legislatures, and (2) exert influence over the distribution of power in a new democracy, as suggested by our argument about parties.

In this section, our discussion of different authoritarian regime types serves two purposes. First, by exploring the regimes where institutions are likely to have sufficient strength to alter the preferences of regime incumbents and potential challengers, we gain purchase on the sample of dictatorships where our expectations about authoritarian institutions are most likely to ring true. Second, we provide historical examples that illustrate the causal mechanisms outlined above. Specifically, we show that authoritarian parties can protect the interests of outgoing dictators in a new democracy directly, by building and winning electoral support, or indirectly, by shaping the governing institutions for a new democracy.

\section{Personalist regimes}

Scholars have distinguished amongst different types of authoritarian regimes and frequently acknowledge that personalist regimes differ from other types of authoritarian rule, such as: military, dominant party, totalitarian, or corporatist. ${ }^{19}$ Researchers have also found that distinguishing amongst different types of dictatorships has been useful for understanding how and when dictatorships transition to democracy and when and with whom dictatorships initiate conflict. $^{20}$ The theoretical underpinnings of these empirical findings focus on institutional differences amongst regimes. For example, Reiter \& Stam show that personalist dictators are more likely to initiate a war with democracies because they are institutionally unconstrained and therefore "unlikely to lose power if they launch an

unsuccessful diplomatic challenge or even a losing war short of catastrophic defeat."21 
Summing up these differences, Geddes argues that the institutional feature that distinguishes personalist regimes from others is that "although personalist regimes have parties and militaries, these organizations have not become sufficiently developed or autonomous to prevent the leader from taking personal control of policy decisions and selection of regime personnel. ${ }^{22}$ Distinct from other types of authoritarian regimes where dictators build mass political support through the provision targeted public goods (dominant party regimes) or govern by repression (military regimes), the basic method of rule in personalist regimes is simply the exchange of particularistic material rewards (private goods) to a select group of regime insiders in return for mobilizing political support. ${ }^{23}$ Here we argue that because legislatures and party systems typically depend on the dictator in personalistic regimes, they are less likely to provide a credible constraint on the dictator and less likely to influence the distribution of power after a transition to democracy than these same institutions in other types of regimes. ${ }^{24}$

In personalist regimes, the dictator does not create a legislature to share power with strong, organised parties or to constrain himself, but to manage elites who challenge him. ${ }^{25}$ The dictator can use the legislature to sanction a legislator who reneges on supporting the dictator, which can deter others. On the flip side, the legislature also gives the dictator a forum to publicly resuscitate a former member of the inner circle. In the Dominican Republic, Rafael Trujillo used the legislature to routinely sanction and reward potential rivals. Any cabinet member he suspected of becoming too powerful or obstinate was sent to Congress to demonstrate his loyalty to Trujillo. ${ }^{26}$ Over time, increasing turnover in the legislature weakened this accountability mechanism. As Trujillo's power weakened, he shuffled legislators through the door at a hyper-inflationary pace, needing more turnover to placate fewer rivals. Wiarda notes that during Trujillo's first term, only two of 12 Senators 
and 19 of 33 Deputies "resigned." 27 In his second term, the Senate saw 12 resignations for 13 seats and 46 resignations for 35 lower house seats. In his third term, 32 Senators (19 seats) and 122 Deputies (42 seats) "resigned." Dr. Hastings Banda similarly used his legislature in Malawi, even resuscitating his once imprisoned (and popular) former Vice President when it became apparent Banda was going to face competitive multiparty elections in 1994. Decalo describes Banda's penchant for rotating legislators in and out of the legislature: "every year between 1970 and 1980 an average of seven Malawi constituencies remained unrepresented in Parliament due to expulsions; and of the 150 members expelled during 1964-1981, forty ended up in prison." ${ }^{28}$ These leaders used legislatures to pit potential rivals, who at various times were also crucial supporters, against each another in competition for blandishments from the dictator. Dictators in these regimes typically did not incubate political constituencies or strong parties with enough lasting power to exert influence of over the distribution of power in a subsequent democracy. Because elites in these regimes use institutions to manage elite conflict, they may help neutralise threats from rival elites within the regime, but may be of little use in defending the regime against threats from powerful groups that stand outside elite circles. ${ }^{29}$ Therefore, institutions in personalist regimes may have little effect on the likelihood of democratization, but may help defend against rival authoritarian threats.

Elites in institutionalised, dominant party regimes, on the other hand, frequently participate and win power in post-transition elections. Political parties in these regimes help build mass support and long-term electoral constituencies which can help protect the interests of authoritarian elites after a transition to democracy. In contrast, elites in military regimes rarely directly participate in post-transition electoral politics. But the institutionalization of a party system during the period of military rule can nonetheless help 
preserve the military's corporate interests in a new democracy because these institutions can both increase the likelihood military allies will be elected in a new democracy and help shape the new electoral rules - often through constituent assemblies.

\section{Dominant party regimes}

An important feature of dominant party regimes is their extensive patronage networks, which help the party mobilise votes. Most dominant party regimes have legislatures (92 percent of country-years), and those that do not are less likely to have the mass party organizations that reach large segments of the population and penetrate many civil society organizations characteristic of most dominant party regimes. ${ }^{30}$ While party regimes without durable and well-institutionalised parties may exert just as much centralised power over the state and citizens as dominant party regimes with legislatures, the contention here is that those with parties have larger distributional networks and hence more mass support, which should translate into more effective voter mobilization should the regime democratise.

When dominant party regimes democratise, former authoritarian parties frequently participate in elections in the subsequent democracy and often do quite well. In Table 1, we list all the independent dominant party (or party- hybrid regimes) in the data set that democratised. All former dominant parties were competitive, winning at least the second largest share of seats in at least one lower house legislative election after the transition to democracy, and a majority (12 of 19) won at least once. ${ }^{31}$ The Colorado Party in Paraguay (ANR-PC) has been dominant in lower house elections since the transition to democracy. 
Table 1: The Fate of Former Dominant Party Regimes after Democratic Transition

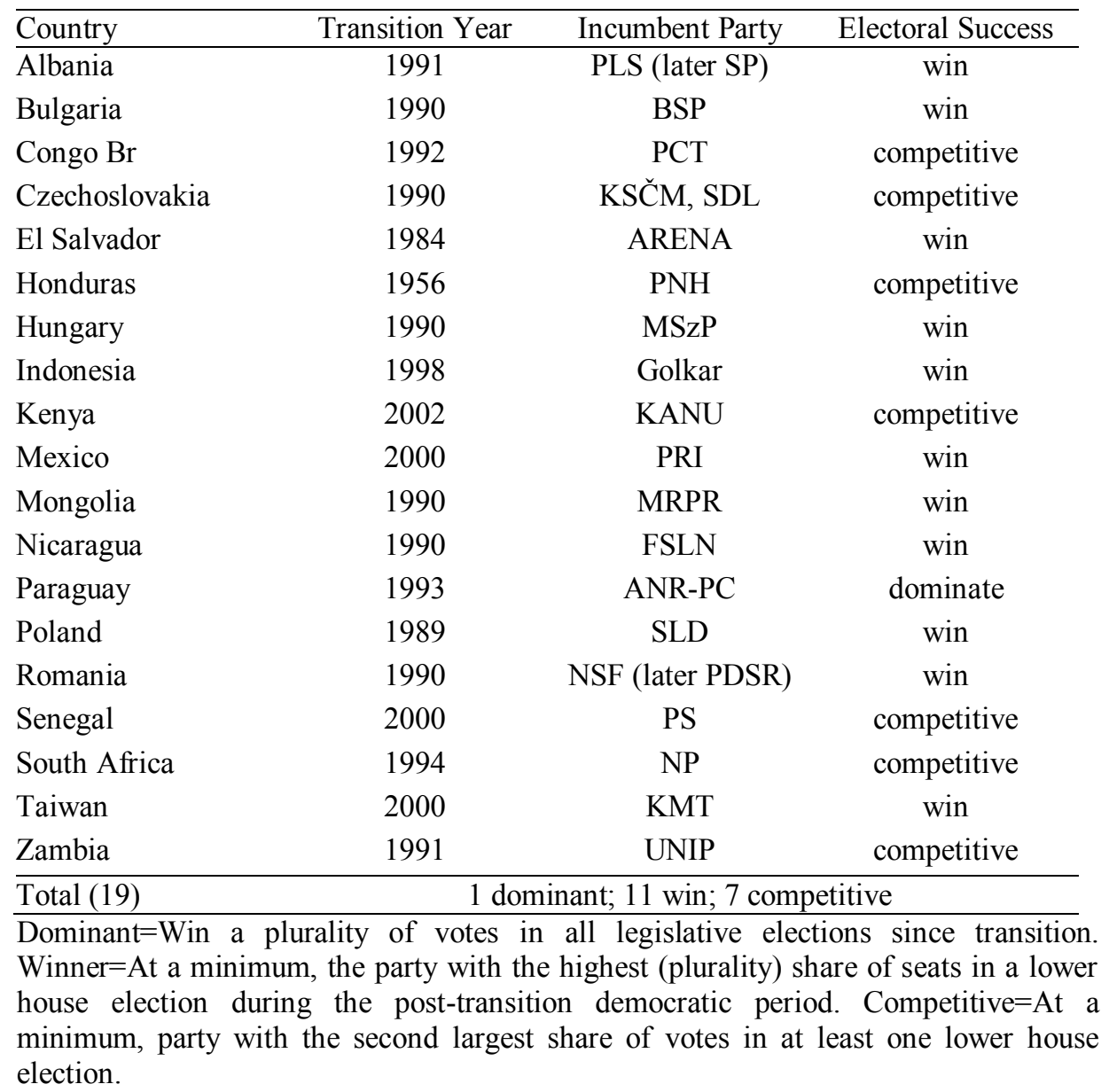

This strategy of building electoral support during authoritarian rule is not exclusive to dominant party regimes. In Brazil, for example, the military used the party system to foster electoral support through patronage in a manner similar to what we observe in many dominant party regimes. In response to a poor electoral showing for the military-backed party (ARENA) in 1974, the Brazilian military substantially increased public spending to win back electoral support. ${ }^{32}$ This patronage system would prove useful in electing 
candidates sympathetic to the military, guaranteeing military prerogatives such as funding for the military, after the transition to democracy. ${ }^{33}$ Thus the mobilizing effect of parties in dominant party regimes may also influence the distribution of power in military regimes.

\section{Military regimes}

Military regimes may stand apart from other types of authoritarian regimes because military elites may not necessarily want to maximise their stay in power. Rather, their highest priorities are often: maintaining military unity, maximizing military budgets, keeping civilian leaders from interfering in their internal affairs, and guaranteeing immunity from human rights prosecution. ${ }^{34}$ Thus, unlike other types of regimes, they may not be averse to democratization if they can guarantee their corporate interests in the subsequent democracy.

Many militaries make bargains with civilian elites which lead to democratization. ${ }^{35}$ These deals are more credible when the military regime has a party system that permits semi-competitive elections, for three reasons. First, the military can pinpoint which parties are likely to win subsequent democratic elections. This ensures that the military bargains with right people. Many militaries in Central and South America made bargains with parties they expected to win the first round of elections. ${ }^{36}$

Second, permitting a semi-competitive party system during the authoritarian period increases the likelihood an ally of the military will be elected as president in the subsequent election. The military can form a close alliance with an existing political party during the authoritarian period, as was the case in Guatemala in 1985 with the election of Christian Democratic candidate Cerezo Arévalo. Or the military can stand up a candidate from its own ranks, as the South Korean and Venezuelan militaries did in 1987 and 1958, respectively. South Korean general Roh Tae-woo won the presidency when the opposition 
split their vote, while Venezuelan Admiral Larrazábal narrowly lost an election he expected to win. ${ }^{37}$ Without the previous authoritarian party system, the military would not have had knowledge of the likely success of their candidate in a relatively free and fair election. In South Korea, therefore, the multiparty election of Roh Tae-woo allowed the military to both democratise and preserve its institutional interests. ${ }^{38}$

A third mechanism through which parties in military regimes can preserve their power after a transition is by influencing the composition of constituent assemblies. Postauthoritarian electoral rules are often chosen in constituent assemblies elected before the transition (Guatemela, Honduras) or by the first democratic legislature acting as a constituent assembly (Brazil). When the military has permitted prior party activity and especially when military-backed patronage parties have developed under military rule, these constituent assemblies are more likely to have significant representation from parties allied with the military.

For example, in Guatemala in 1984, the military oversaw the election of a Constituent Assembly which wrote the new constitution under which subsequent elections have been conducted. The military-allied Christian Democrats won the largest share of seats in the Constituent Assembly, while the Social Democrats sat out the election entirely. In this case cases, opposition parties were banned from participating in the Constituent Assembly elections, and the military succeeded in using elected Constituent Assembly to write the new electoral rules in its favor.

The Thai military transitioned to democratic rule three times between 1973 and 1992. Previous to two of these transitions (1988 and 1992) the military allowed political parties to compete in elections. The Constituent Assemblies that wrote the electoral rules used in the subsequent democratic periods were dominated by military backed parties and 
the military came very close to getting their preferred candidate in office during the subsequent democratic periods. ${ }^{39}$ Preceding the democratic transition in 1973, however, the military had mostly functioned without parties. They banned all political parties for nearly ten years (1958-1968) and only stood up a legislature for less than three years (1968-1971) after the Constitution had sat untouched in the Constituent Assembly for nearly eight years. ${ }^{40}$ Far from giving the generals confidence that relatively free and fair elections would not endanger their corporate interests, these parties prompted the military to shut down the legislature in 1971 . The military did not cede power to civilians until nearly half a million protesters flooded the streets of Bangkok and over 1500 deaths brought down the regime in $1973{ }^{41}$ To resolve the ensuing political crisis in late 1973, the King picked a constitutional assembly which in turn selected the first legislature - one largely absent any militarybacked parties. After mostly opposing the legislature (1958-1968, 1971-1973) and otherwise abusing it (1969-1971), the military had very little say in the ensuing democracy after the transition in 1973 . The Thai case suggests that military regimes with parties may end in democracy more quickly, but with considerably less violence. Having a functioning party system in place during military rule eases the transition to democracy by ensuring military elites their interests are better represented in the ensuing democracy.

Distinguishing the effect of legislatures from parties may be particularly difficult in military regimes, especially those that use constituent assemblies to help write electoral laws that are eventually implemented in the ensuing democracy. However, the mere presence of a legislature does not guarantee that military elites can successfully do this, nor does the absence of a legislature prevent the military from writing the electoral rules in its favor (see Pinochet's 1981 Constitution). However, the presence of a legislature with sufficient teeth to circumscribe the power of the military, we argue, may be necessary to 
help coopt groups that press for democratization, whereas parties may be a byproduct of this process. Concerning the distribution of power in new democracies, however, the presence of parties during military rule may be more helpful than legislatures in influencing the outcome of constituent assemblies and gauging the future electoral support of would-be military allies in a new democracy.

This discussion of political institutions in different types of regimes suggests that our hypotheses merit an important qualification: Because parties and legislatures in personalist regimes may be weaker than in other types of regimes, the evidence for Hypotheses 1-5 should be weaker for personalist regimes. Below we examine the evidence for all authoritarian regimes and then separately for personalist and non-personalist regimes.

\section{Data and Methods}

To test the preceding hypotheses we use an updated version of Geddes data on authoritarian regimes that codes two types of regime failure: transition to a subsequent dictatorship and a democratic transition. ${ }^{42}$ We use regime data instead of authoritarian spells or leader data for two reasons. First, empirical models that estimate the likelihood of transition between dictatorship and democracy or changes in the level of "democraticness" (e.g. Polity scores) do not capture transitions from one dictatorship to another. For example, a variable that only marks a transition from dictatorship to democracy cannot model the regime failure that occurred during the Iranian Revolution in 1979, when Shah Reza Pahlavi was deposed. Further, graded measures of democracy, such as changes in the Polity score, can conflate changes in the level of "democraticness" with regime transition. For example, the Iranian Revolution is coded as an increase in the Polity score from -10 to 0, while Mobutu Sese Seko's introduction of multipartyism in 1992 is coded as an increase in the Polity score 
from -8 to 0 . Chile's democratic transition in 1989 is coded as an increase from -1 to 8 . The Polity scale treats these changes as roughly equivalent $(10,8$, and 9 point increases respectively). However, the first of these changes is transition to a subsequent dictatorship (Iran); the second entails no transition whatsoever (former Zaire); and the last is a democratic transition (Chile).

Second, empirical models that estimate the likelihood of leadership turnover in dictatorships capture both regular and irregular transfers of power. ${ }^{43}$ For example, using leader failure as the dependent variable assumes that exit from a coup or transition to democracy follow the same data generating process as regularised leadership turnover within an authoritarian regime spell, as occurs in many dominant party regimes such as Mexico's PRI, Tanzania's CCM, and the last few decades of Communist rule in China. A leader failure variable cannot distinguish between term-limited leadership change in Mexico under PRI rule (Salinas to Zedillo) and the electoral defeat of the PRI in 2000 (Zedillo to Fox). To include regularised turnover within the authoritarian regime spell (Salinas to Zedillo) could bias our estimates because regimes which tend to have regularised turnover also tend to be the longest lasting. To circumvent this issue of regular leadership turnover within an authoritarian regime, one might look only at irregular turnover (excluding regular failures). However, this strategy excludes democratic transitions - many of which are coded as regular leadership turnover.

The data on authoritarian parties and legislatures is from Gandhi. ${ }^{44}$ The legislature variable measures whether a legislature exists in a given year. As Table 2 shows, legislatures are most common in dominant party regimes (92 per cent of regime-years) and least common in military regimes (37 per cent of regime years). All regime types, with the exception of monarchies, are more likely to have legislatures after the Cold War, perhaps 
reflecting greater international pressure to stand up democratic-looking institutions in this period. The 'parties' variable can take one of three values: 0 for no parties; 1 for one party only; and 2 for more than one party. ${ }^{45}$ As with legislatures, parties are more likely during the post-Cold War period than previously.

The lower panel of Table 2 shows the cross-tabs for parties and legislatures. Not all regimes that lack a legislature are devoid of de facto parties. Consider, for example, Pinochet's rule in Chile, where parties formed during the long democratic period that preceded his rule continued to operate even though Pinochet ruled without the help of a legislature. In El Salvador during the early 1980s, the military allowed some political parties to operate and began a negotiated transition with the leader of the Christian Democratic Party, even though the legislature did not meet. ${ }^{46}$ Further, not all regimes with legislatures have parties. This most often occurs in monarchies or highly personalistic regimes such as Qaddafi's in Libya where the dictator rules with a legislature, but there are no identifiable political parties. When there is no legislature 45 per cent of the regime-years also have no parties, but 20 per cent have one party, and 35 per cent have more than one de facto party. In regimes with a legislature, 6 per cent have no parties (mostly monarchies), 44 per cent have only one party, and 50 per cent have more than one party. Thus authoritarian legislatures and parties do not always appear in the same place at the same time, giving us meaningful variation to test the predictions outlined above. To model regime survival, we employ a time-series, cross-section probit model with controls for time dependence; we include polynomial transformations of duration time (duration and duration $\left.{ }^{2}\right){ }^{47}$ 
Table 2: Political Institutions in Authoritarian Regimes

\begin{tabular}{lcccc}
\hline Sample & Dominant Party & Military & Personalist & Monarchy \\
\hline Legislatures & & & & \\
$1946-1989$ & $90 \%$ & $33 \%$ & $75 \%$ & $53 \%$ \\
$1990-2002$ & $99 \%$ & $56 \%$ & $84 \%$ & $47 \%$ \\
$1946-2002$ & $92 \%$ & $37 \%$ & $77 \%$ & $52 \%$ \\
& & & & \\
Parties & 1.34 & 1.14 & 1.32 & 0.62 \\
$1946-1989$ & 1.62 & 1.79 & 1.79 & 0.70 \\
$1990-2002$ & 1.40 & 1.27 & 1.46 & 0.64 \\
\hline $1946-2002$ & & & &
\end{tabular}

Legislatures and parties

\begin{tabular}{|c|c|c|c|}
\hline \multicolumn{4}{|c|}{ Column percentages reported } \\
\hline Parties & No Legislature & Legislature & Total \\
\hline$\overline{\text { Zero }}$ & $45 \%$ & $6 \%$ & $15 \%$ \\
\hline One & $20 \%$ & $44 \%$ & $39 \%$ \\
\hline More than one & $35 \%$ & $50 \%$ & $46 \%$ \\
\hline Total & $100 \%$ & $100 \%$ & $100 \%$ \\
\hline
\end{tabular}

Years covered: 1946-2002. Totals in cells describe country-year observations. Party-based regimes include single-party hybrids; and military regimes includes military-personalist hybrids.

We test two dependent variables: transition to a democracy and transition to a subsequent authoritarian regime. Previous work on democratization, which models transitions between non-democracies and democracies, does not examine transitions between authoritarian regimes. ${ }^{48}$ Earlier research on the authoritarian regime survival which focuses only on the survival of particular regimes, groups together democratization and transition to a subsequent autocracy in the dependent variable. ${ }^{49}$

\section{Addressing simultaneity}

Authoritarian elites may choose to allow multiple parties as part of the transition process, particularly a transition to democracy. To code the dependent variables (transition to democracy and subsequent dictatorship) we mark the year of the event that ends the 
authoritarian regime. However, the decision to begin a democratic transition may take place in a year (or years) prior to the regime failure event. Thus the process we are attempting to model, regime transitions, may in part determine the number of parties. One way to address this simultaneity issue is to lag the parties variable two or more years. However, this entails an assumption (1) about how long 'transition' periods last and (2) that all countries that allowed multiple parties prior to the actual transfer of power did so because elites had committed to democratization. In some cases, such as Benin (1990) or Malawi (1993), the introduction of multiple parties was part and parcel of the democratization process. However, in other cases, such as Argentina (1979), this is probably not the case. The Argentine military retreated to the barracks in 1983 because of declining political support resulting from a military defeat in the Malvinas conflict in $1982 .{ }^{50}$ In this case, the decision to allow multiple parties appears to have prior to the event that tipped the military towards democratization.

Further, some countries that introduced multi-party systems in the wake of the Cold War did not in the end democratise - even though they faced the same international 'pressure to democratise' as many countries that did democratise. For example, Mobutu Sese Seko (former Zaire) opened up the party system in the early 1990s, allowing dozens of opposition parties to participate in the General Conference in $1992 .^{51}$ However, multipartyism was not a prelude to democratic transition. Rather, Mobutu used multi-partyism to manipulate and divide the opposition without ever making serious movement towards democratization. Therefore we cannot assume that all transitions to multi-partyism necessarily lead to democratization. That said, the introduction of multiple parties is often a strategy used to placate or co-opt the opposition groups that can credibly threaten the 
power. Thus the incumbent's perception of instability can influence the decision to allow multiple parties, creating a simultaneity problem.

To address the simultaneity issue without making assumptions about the length of transition periods or the determinism of introducing multi-partyism, we estimate simultaneous equations where the dependent variable in one equation is the number of parties and the dependent variable in a second equation is regime transition (either to democracy or to dictatorship). For the transition to democracy equation, for example, we test the following structural equations:

$$
\begin{aligned}
& \text { Parties }=\gamma_{1} \text { Democ }^{*}+\beta_{1} X_{1}+u_{1} \\
& \text { Democ }=\gamma_{2} \text { Parties } *+\beta_{2} X_{2}+u_{2}
\end{aligned}
$$

Before we estimate (1) and (2), we estimate first stage equations using all the explanatory variables $\left(X_{1}, X_{2}\right)$ from both equations to obtain fitted values of both dependent variables to use as instruments for Parties ${ }^{*}$ and Democ ${ }^{*}$ :

$$
\begin{aligned}
& \text { Parties }=\beta_{3} X_{1}+\beta_{4} X_{2}+u_{3} \\
& \text { Democ }=\beta_{5} X_{1}+\beta_{6} X_{2}+u_{4}
\end{aligned}
$$

We then substitute Parties and Dê̂oc from (3) and (4) for Parties ${ }^{*}$ and Democ ${ }^{*}$ in (1) and (2). This strategy yields unbiased estimates of $\gamma_{1}$ and $\gamma_{2}$ that account for simultaneity bias. However, the standard errors may be incorrect. ${ }^{52}$ 
We follow the same procedure to estimate the effect of legislatures, substituting Legislature for Parties in (1) and (3). In equations where we test the effect of both parties and legislature on the likelihood of transition to democracy (or subsequent dictatorship), we estimate the following system of equations (omitting the subscripts).

$$
\begin{aligned}
& \text { Parties }=\beta X_{1}+\beta X_{2}+u \\
& \text { Legislature }=\beta X_{1}+\beta X_{2}+u
\end{aligned}
$$

We then calculate the fitted values for both Parties and Legisilature from (5) and (6) to use as instruments in the following second-stage equation.

$$
\text { Democracy }=\text { Par̂ties }+ \text { Legis } \hat{l} \text { ature }+\beta X_{2}+u
$$

In this system of equations, we use the same set of explanatory variables $\left(X_{1}\right)$ for both Parties and Legislature. If we assume that the decision to create a legislature is exogenous to transition likelihoods and treat Legislature as an exogenous control variable, the estimates we report below do not substantively change. To err on the side of caution, though, we report results that use an instrument for Legislature in (7).

We estimate (1) and (3) with an ordered probit and (2) and (4) with a probit. To save space, we only report the results of the outcome equations where the dependent variable is the likelihood of transition to Democracy or to Dictatorship. The outcome equations for the institutional variables (3) are available in the Appendix (A-1). We correct the standard errors in the second-stage equations - (2) and (7) - according to the method suggested by Maddala. ${ }^{53} 54$ 
The explanatory variables in the first stage equations $\left(X_{1}\right)$ include: Ethnic fractionalization, Percent Islamic, former French colony, former Spanish colony, Time, Time $^{2}$, and Time ${ }^{3}$ where Time $=$ CalendarYear ${ }_{i}-1945 .^{55}$ We also include the control variables in the outcome equation ( $X_{2}$, described below) as explanatory variables. To save space we do not report the results of the first stage models (A-1), but note that ethnic fractionalization, former Spanish colonies, higher growth rates, and higher neighbouring country democracy all increase the likelihood of parties, while higher percent Islamic, former French colonies, higher GDP per capita, and the Cold War period all reduce the likelihood of parties. The results from the first stage Legislature equation mirror those of the Parties equation, except that growth has no effect on legislatures, level of development is positively correlated with legislatures, and Spanish colony has a negative effect while French colony has a positive effect.

The control variables in the outcome equation $\left(X_{2}\right)$ include: LogGDPpc, Growth, Cold War, NeighbourDemocracy, and a dummy variable for Military regimes. ${ }^{56}$ We include Cold War because international pressure on authoritarian regimes to appear democratic by holding elections and standing up legislatures increases in the post-Cold War world, as does pressure to democratise. Also, super power states were more likely to tolerate and subsidise authoritarian regimes during the Cold War. Economic growth in most of the developing world has also been much slower in the post-Cold War period than in the 1960s and 1970s, and the probability of regime failure is higher in the post-Cold War period. Thus, we do not want the institutions variables to simply proxy for a change in the international environment. The level of development $(\log G D P p c)$ controls for the fact that richer countries may be more likely to democratise (a version of modernization theory) and may 
be more likely to have a legislature. Neighbour Democracy controls for the diffusion effects of democratic institutions in neighbouring countries. ${ }^{57}$ It is measured as the share of countries with capitol cities within $2000 \mathrm{~km}$ of the target country that are democracies. We include a control for military regimes because they are less likely to have institutions than dominant party regimes, and previous research finds that military regimes are the most unstable regime type. ${ }^{58}$

\section{Results}

The first three columns of Table 3 look at the sample of all regimes. The first model includes Parties, the second Legislature, and the third both. The coefficients for Parties are positive and statistically significant for transitions to democracy but not for transitions to a subsequent dictatorship. The coefficients for Legislature are negative for both types of regime failure, but only statistically significant for a transition to a subsequent dictatorship. This suggests that parties increase the likelihood of democratization but have little effect on transitions to a subsequent authoritarian regime, while legislatures decrease the likelihood of transitions to dictatorship but have little effect on democratization. ${ }^{59}$

Next we separate non-personalist regimes from personalist regimes. The results in columns 4-6 for non-personalist regimes mirror those of the first three columns, but are slightly stronger: Parties increase the likelihood of democratization while legislatures decrease the chances of a subsequent authoritarian regime taking power, though this latter effect is not statistically significant. The results in the final three columns are quite different. In personalist regimes, parties have little effect on the likelihood of either type of transition, while legislatures are associated with a lower likelihood of democratization. 
Table 3: Authoritarian Institutions and Transitions to Democracy and Dictatorship

\begin{tabular}{|c|c|c|c|c|c|c|c|c|c|}
\hline \multirow{2}{*}{$\begin{array}{l}\text { Model } \\
\text { Transition to }\end{array}$} & $(1)$ & $(2)$ & (3) & (4) & $(5)$ & \multirow[t]{2}{*}{$(6)$} & (7) & $(8)$ & \multirow[t]{2}{*}{$(9)$} \\
\hline & & & & & & & & & \\
\hline \multicolumn{10}{|l|}{ Democracy } \\
\hline & \multicolumn{3}{|c|}{ All Regimes (1-3) } & \multicolumn{3}{|c|}{$\underline{\text { Non-personalist (4-6) }}$} & \multicolumn{3}{|c|}{$\underline{\text { Personalist (7-9) }}$} \\
\hline Parties & $\begin{array}{c}0.559 * * \\
(0.13)\end{array}$ & & $\begin{array}{c}0.530 * * \\
(0.13)\end{array}$ & $\begin{array}{c}0.688 * * \\
(0.18)\end{array}$ & & $\begin{array}{c}0.682 * * \\
(0.18)\end{array}$ & $\begin{array}{l}0.170 \\
(0.21)\end{array}$ & & $\begin{array}{l}0.115 \\
(0.20)\end{array}$ \\
\hline Legislature & & $\begin{array}{c}-0.201+ \\
(0.11)\end{array}$ & $\begin{array}{c}-0.078 \\
(0.12)\end{array}$ & & $\begin{array}{c}-0.088 \\
(0.10)\end{array}$ & $\begin{array}{r}-0.013 \\
(0.11)\end{array}$ & & $\begin{array}{l}-0.395 \\
(0.37)\end{array}$ & $\begin{array}{l}-0.347 \\
(0.37)\end{array}$ \\
\hline Growth & $\begin{array}{c}-3.641 * * \\
(0.96)\end{array}$ & $\begin{array}{c}-2.682^{* *} \\
(0.87)\end{array}$ & $\begin{array}{c}-3.535^{* *} \\
(0.97)\end{array}$ & $\begin{array}{c}-4.495^{* *} \\
(1.09)\end{array}$ & $\begin{array}{c}-3.433 * * \\
(1.01)\end{array}$ & $\begin{array}{c}-4.467^{* *} \\
(1.08)\end{array}$ & $\begin{array}{c}-1.554 \\
(2.01)\end{array}$ & $\begin{array}{r}-1.075 \\
(1.88)\end{array}$ & $\begin{array}{r}-1.372 \\
(2.06)\end{array}$ \\
\hline Military & $\begin{array}{c}1.192^{* *} \\
(0.15)\end{array}$ & $\begin{array}{c}0.959 * * \\
(0.20)\end{array}$ & $\begin{array}{c}1.105^{* *} \\
(0.21)\end{array}$ & $\begin{array}{c}1.205 * * \\
(0.18)\end{array}$ & $\begin{array}{c}1.124 * * \\
(0.22)\end{array}$ & $\begin{array}{c}1.190 * * \\
(0.22)\end{array}$ & & & \\
\hline $\ln (\mathrm{GDPpc})$ & $\begin{array}{l}0.004 \\
(0.08)\end{array}$ & $\begin{array}{r}-0.042 \\
(0.08)\end{array}$ & $\begin{array}{c}-0.008 \\
(0.09)\end{array}$ & $\begin{array}{l}0.004 \\
(0.10)\end{array}$ & $\begin{array}{c}-0.008 \\
(0.10)\end{array}$ & $\begin{array}{l}0.002 \\
(0.10)\end{array}$ & $\begin{array}{l}0.069 \\
(0.17)\end{array}$ & $\begin{array}{l}0.117 \\
(0.18)\end{array}$ & $\begin{array}{l}0.109 \\
(0.17)\end{array}$ \\
\hline Neighbour polity & $\begin{array}{c}0.071 \\
(0.16)\end{array}$ & $\begin{array}{c}0.794 * * \\
(0.26)\end{array}$ & $\begin{array}{l}0.225 \\
(0.30)\end{array}$ & $\begin{array}{c}-0.062 \\
(0.23)\end{array}$ & $\begin{array}{c}0.582^{*} \\
(0.25)\end{array}$ & $\begin{array}{r}-0.040 \\
(0.29)\end{array}$ & $\begin{array}{l}0.209 \\
(0.22)\end{array}$ & $\begin{array}{l}1.160 \\
(0.86)\end{array}$ & $\begin{array}{l}1.028 \\
(0.87)\end{array}$ \\
\hline Cold war & $\begin{array}{l}-0.058 \\
(0.15)\end{array}$ & $\begin{array}{c}-0.385^{* *} \\
(0.12)\end{array}$ & $\begin{array}{l}-0.083 \\
(0.15)\end{array}$ & $\begin{array}{c}-0.052 \\
(0.18)\end{array}$ & $\begin{array}{c}-0.373^{*} \\
(0.15)\end{array}$ & $\begin{array}{c}-0.058 \\
(0.17)\end{array}$ & $\begin{array}{c}-0.339 \\
(0.32)\end{array}$ & $\begin{array}{c}-0.349 \\
(0.26)\end{array}$ & $\begin{array}{l}-0.263 \\
(0.31)\end{array}$ \\
\hline Log likelihood & -287.6 & -297.3 & -287.3 & -216.6 & -226.9 & -216.6 & -69.1 & -68.619 & -68.432 \\
\hline Observations & 3768 & 3768 & 3768 & 2808 & 2808 & 2808 & 960 & 960 & 960 \\
\hline $\begin{array}{l}\text { Per cent correctly } \\
\text { classified }\end{array}$ & 98.1 & 98.1 & 98.1 & 98.0 & 98.0 & 98.0 & 98.4 & 98.4 & 98.4 \\
\hline \multicolumn{10}{|l|}{ Transition to } \\
\hline$\overline{\text { Dictatorship }}$ & \multirow{2}{*}{\multicolumn{3}{|c|}{ All Regimes (1-3) }} & \multirow{2}{*}{\multicolumn{3}{|c|}{$\underline{\text { Non-personalist (4-6) }}$}} & \multirow{2}{*}{\multicolumn{3}{|c|}{$\underline{\text { Personalist (7-9) }}$}} \\
\hline & & & & & & & & & \\
\hline Parties & $\begin{array}{l}0.066 \\
(0.11)\end{array}$ & & $\begin{array}{l}0.056 \\
(0.11)\end{array}$ & $\begin{array}{l}-0.015 \\
(0.18)\end{array}$ & & $\begin{array}{l}0.004 \\
(0.17)\end{array}$ & $\begin{array}{l}0.085 \\
(0.12)\end{array}$ & & $\begin{array}{l}0.080 \\
(0.12)\end{array}$ \\
\hline Legislature & & $\begin{array}{c}-0.199 * \\
(0.09)\end{array}$ & $\begin{array}{c}-0.197 * \\
(0.09)\end{array}$ & & $\begin{array}{l}-0.164 \\
(0.10)\end{array}$ & $\begin{array}{l}-0.164 \\
(0.10)\end{array}$ & & $\begin{array}{l}-0.069 \\
(0.21)\end{array}$ & $\begin{array}{r}-0.052 \\
(0.21)\end{array}$ \\
\hline Growth & $\begin{array}{l}-0.311 \\
(0.95)\end{array}$ & $\begin{array}{r}-0.191 \\
(0.92)\end{array}$ & $\begin{array}{l}-0.254 \\
(0.93)\end{array}$ & $\begin{array}{l}-0.768 \\
(1.41)\end{array}$ & $\begin{array}{l}-0.651 \\
(1.38)\end{array}$ & $\begin{array}{l}-0.654 \\
(1.38)\end{array}$ & $\begin{array}{l}0.796 \\
(1.31)\end{array}$ & $\begin{array}{l}0.948 \\
(1.28)\end{array}$ & $\begin{array}{l}0.781 \\
(1.30)\end{array}$ \\
\hline Military & $\begin{array}{l}0.306^{*} \\
(0.16)\end{array}$ & $\begin{array}{l}0.095 \\
(0.18)\end{array}$ & $\begin{array}{l}0.095 \\
(0.18)\end{array}$ & $\begin{array}{c}0.510^{* *} \\
(0.18)\end{array}$ & $\begin{array}{l}0.327 \\
(0.20)\end{array}$ & $\begin{array}{l}0.326 \\
(0.21)\end{array}$ & & & \\
\hline $\ln (\mathrm{GDPpc})$ & $\begin{array}{c}-0.262 * * \\
(0.07)\end{array}$ & $\begin{array}{c}-0.299 * * \\
(0.07)\end{array}$ & $\begin{array}{c}-0.296^{* *} \\
(0.07)\end{array}$ & $\begin{array}{c}-0.298 * * \\
(0.08)\end{array}$ & $\begin{array}{c}-0.327^{* *} \\
(0.09)\end{array}$ & $\begin{array}{c}-0.327^{* *} \\
(0.09)\end{array}$ & $\begin{array}{l}-0.135 \\
(0.13)\end{array}$ & $\begin{array}{l}-0.114 \\
(0.13)\end{array}$ & $\begin{array}{l}-0.127 \\
(0.13)\end{array}$ \\
\hline Neighbour polity & $\begin{array}{l}-0.125 \\
(0.19)\end{array}$ & $\begin{array}{l}0.264 \\
(0.24)\end{array}$ & $\begin{array}{l}0.214 \\
(0.25)\end{array}$ & $\begin{array}{l}0.105 \\
(0.25)\end{array}$ & $\begin{array}{l}0.338 \\
(0.27)\end{array}$ & $\begin{array}{l}0.334 \\
(0.30)\end{array}$ & $\begin{array}{c}-0.425+ \\
(0.24)\end{array}$ & $\begin{array}{l}-0.218 \\
(0.60)\end{array}$ & $\begin{array}{l}-0.299 \\
(0.62)\end{array}$ \\
\hline Cold war & $\begin{array}{l}0.061 \\
(0.15)\end{array}$ & $\begin{array}{l}0.017 \\
(0.12)\end{array}$ & $\begin{array}{l}0.054 \\
(0.14)\end{array}$ & $\begin{array}{l}-0.071 \\
(0.20)\end{array}$ & $\begin{array}{l}-0.090 \\
(0.15)\end{array}$ & $\begin{array}{l}-0.088 \\
(0.19)\end{array}$ & $\begin{array}{l}0.233 \\
(0.24)\end{array}$ & $\begin{array}{l}0.173 \\
(0.23)\end{array}$ & $\begin{array}{l}0.247 \\
(0.26)\end{array}$ \\
\hline Log likelihood & -416.059 & -413.848 & -413.712 & -243.615 & -242.082 & -242.082 & -161.637 & -161.775 & -161.603 \\
\hline Observations & 3768 & 3768 & 3768 & 2808 & 2808 & 2808 & 960 & 960 & 960 \\
\hline $\begin{array}{l}\text { Per cent correctly } \\
\text { classified }\end{array}$ & 97.6 & 97.6 & 97.6 & 98.2 & 98.2 & 98.2 & 95.8 & 95.8 & 95.8 \\
\hline
\end{tabular}


Table 4 reports the predicted probabilities of transition for three types of regimes under different institutional settings. ${ }^{60}$ The first pattern to note is that parties increase the likelihood of democratization in military and party regimes, but have little effect on democratization in personalist regimes. In party regimes, which have a low baseline likelihood of transition to democracy, parties increase the chances of democratization from 0.1 per cent to 0.5 per cent with one party and again to 2.3 per cent with multiple parties. In military regimes, the effect of parties is much stronger, increasing the likelihood of democratization from less than 1 per cent to nearly 4 per cent with one party and to almost 12 per cent with multiple parties. This pattern is consistent with the first hypothesis, though the effect of parties is strongest when there are multiple parties. One interpretation of the finding that multiple parties have a stronger effect on the likelihood of democratization is that incumbent parties must build broader and deeper support coalitions during the authoritarian period, which in turn could help preserve power for the authoritarian elite in a new democracy. Second, we expected legislatures to decrease the likelihood of democratization. This pattern is only observed in personalist regimes, however. Given the paucity of dominant party regimes with no legislature (see Table 2), we cannot conclude that legislatures in these regimes substantively affect the likelihood of democratization. Thus the only regime type where legislatures really deter democratization is personalist.

Third, parties decrease the likelihood of transition to a subsequent authoritarian regime in non-personalist regimes, but increase this transition likelihood by in personalist regimes. The finding that parties destabilise personalist regimes by increasing the likelihood of a transition to a subsequent dictatorship is consistent with the Hypothesis 3 . However, the negative (in non-personal regimes) and positive effect (in personalist regimes) of parties on the likelihood of transition to another autocracy are relatively small. Finally, legislatures 
decrease the likelihood of transition to a subsequent authoritarian regime in all regimes, but this finding is strongest for military and dominant party regimes. In the latter, this effect is quite large (decreasing the likelihood by 50 per cent below the baseline) but this is driven by only a handful of very unstable party regimes that were not sufficiently institutionalised to even stand up a legislature. In military regimes, legislatures cut the likelihood of transition to another dictatorship by slightly less than one half.

Table 4: Predicted probabilities of transition

\begin{tabular}{|c|c|c|c|c|c|c|c|}
\hline \multicolumn{8}{|c|}{ Probabilities of transition from columns $6 \& 9$ (Table 3 ) } \\
\hline & & \multicolumn{2}{|c|}{ Military } & \multicolumn{2}{|c|}{ Party-based } & \multicolumn{2}{|c|}{ Personalist } \\
\hline$\underline{\text { Leg. }}$ & $\underline{\text { Parties }}$ & $\hat{P}($ Dem. $)$ & $\hat{P}($ Dict.$)$ & $\hat{P}($ Dem. $)$ & $\hat{P}($ Dict. $)$ & $\hat{P}($ Dem. $)$ & $\hat{P}($ Dict. $)$ \\
\hline 0 & 0 & $0.9 \%$ & $4.2 \%$ & $0.1 \%$ & $4.1 \%$ & $4.4 \%$ & $3.0 \%$ \\
\hline 0 & 1 & $3.8 \%$ & $3.7 \%$ & $0.6 \%$ & $3.7 \%$ & $4.4 \%$ & $3.1 \%$ \\
\hline 0 & 2 & $11.5 \%$ & $3.6 \%$ & $2.5 \%$ & $3.7 \%$ & $5.0 \%$ & $3.6 \%$ \\
\hline 1 & 0 & $0.9 \%$ & $2.5 \%$ & $0.1 \%$ & $2.1 \%$ & $0.8 \%$ & $2.4 \%$ \\
\hline 1 & 1 & $3.9 \%$ & $2.2 \%$ & $0.5 \%$ & $1.9 \%$ & $0.8 \%$ & $2.6 \%$ \\
\hline 1 & 2 & $11.8 \%$ & $2.1 \%$ & $2.3 \%$ & $1.9 \%$ & $1.1 \%$ & $3.2 \%$ \\
\hline
\end{tabular}

'Zero parties' is understood as the median Parties within the subsample Parties 's that fall below the first cut-off in the first stage ordered probit ( Parties $\in(0,1,2)$ ). 'Two parties' is understood as the median Parties within the subsample of Parties 's that fall above the second cut-off in the first-stage ordered probit ( Parties $\in(0,1,2)$ ).

In short, parties increase the prospects of democratization in military and dominant party regimes and may actually increase the likelihood of transition to a subsequent authoritarian regime in personalist dictatorships. This suggests that, far stabilizing dictators, parties can increase the likelihood of regime transition - albeit in different directions for 
distinct types of regimes. Legislatures, on the other hand, decrease the likelihood of transition to a subsequent dictatorship in all regimes perhaps as a mechanism to co-opt and deter authoritarian rivals. ${ }^{61}$ In personalist regimes, legislatures appear to decrease the prospects for democratization as well. In sum, there is some evidence to suggest that parties destabilise authoritarian regimes while legislatures help them survive in power.

A number of other findings are worth noting. First military regimes are more likely to democratise than other types of regimes, a finding consistent previous research. ${ }^{62}$ While there is some evidence that military regimes are more susceptible to falling to subsequent authoritarian regime, their instability relative to other regimes is most evident in the democracy equations. Second, higher GDP per capita lowers the likelihood of transition to a subsequent dictatorship. If most of these transitions are coups, this finding is consistent with Londregan and Poole's findings. ${ }^{63}$ However, this finding is only robust for non-personalist regimes, suggesting that a coup trap may only be the province of party and military regimes. Finally, short-term economic growth appears to be a factor that stabilises authoritarian regimes, but this effect is strongest in the democracy equations. This finding may reflect that fact that economic crisis is strongly associated with democratization. ${ }^{64}$

\section{Robustness}

We conducted several robustness checks, the results of which are available in an online Appendix. First, we included random effects in the second stage equation to address unit heterogeneity (A-2). Second, to ensure that monarchies were not driving the results, we tested models that included a dummy variable for monarchies and models that excluded monarchies from the analysis (A-3 and A-4). Third, we controlled for oil rents in all equations (A-5); this reduced the sample size, mostly by omitting years before 1960 . 
Fourth, we tested models that exclude economic growth from the analysis because it is possible this variable is not exogenous as political instability may affect growth outcomes (A-6). Fifth, we tested models in which we lagged the number of parties by two years to further address the possibility that multi-partyism is endogenous to democratization (A-7). The results reported in Table 3 of the manuscript are robust to all of these alternative specifications. Finally, we tested models without control variables for military regimes (A8). Without controlling for military regimes, the results show that in non-personal regimes, parties increase the likelihood of democratization and legislatures decrease the likelihood of democratization. This evidence is consistent with Hypotheses 2 and 4. Military regimes are less likely to have legislatures than party-based regimes and are also more likely to democratise, perhaps for reasons that are unrelated to political institutions. ${ }^{65}$ Thus we view this variable as an important control. In short, including the control for Military does not alter the results for parties but it does for legislatures - in a direction that works against Hypothesis 2.

We conducted three additional empirical tests to better understand how parties and legislatures affect democratization. First, we explored the empirical relationship between parties and democratization by estimating the effect of one party and more than one party separately (A-9). To do this, we constructed separate instruments for one-party only and multiple parties using (5). ${ }^{66} \mathrm{We}$ found that even having only one party increases the likelihood of democratization, though the effect for multiple parties is much stronger, as suggested by the predicted probabilities in Table 4. For example, in models similar to columns 1 and 3 in Table 3, the coefficients for one-party are 0.32 and 0.50 (neither statistically significant, though), ${ }^{67}$ while the coefficients for more than one-party are 0.77 and 0.86 (both statistically significant at the 0.01 level). This suggests that the bulk of the 
parties effect on democratization lies in multiple parties. One interpretation of this result is that incumbent parties must develop deeper support networks when there is at least nominal political competition than when it is absent. If the main argument for parties is correct, deeper support coalitions should be more likely to protect elite interests after a transition to democracy.

Second, we explored the interaction between Parties and Legisilature to understand if the democratizing effect of parties is only present in regimes that also stand up a legislature (A-10). To do this, we calculated an interaction term from the instruments derived in (5) and (6) above. These models are the same as those in columns 6 and 9 in Table 3, but with the addition of an interaction between Parties and Legisiature. The interaction term is small and indistinguishable from zero in the personalist-only sample. In the sample of non-personalist regimes, however, the coefficients for both Parties and Parties * Legislature are positive and statistically significant. With no legislature, the coefficient for Parties is 0.65 and when a legislature is also in place this coefficient increases to 0.85 . This finding is consistent with Hypothesis 4, though the presence of a legislature appears to increase the democratizing effect of parties.

Last, we tested models that allow the effect of institutions to vary by regime type in the non-personalist sample by including interactions between Military and Parties and Military and Legisilature (A-11). ${ }^{68}$ We find that Parties increases the likelihood of democratization in both military and party regimes; however, the magnitude of the effect is larger in party regimes. The coefficient for Parties, reflecting the marginal effect in party regimes, is 0.98 and statistically different from zero at the 0.01 level. The coefficient for Parties + Parties * Military, reflecting the marginal effect in military regimes, is 0.38 
and statistically different from zero at the 0.10 level. ${ }^{69}$ This suggests that while parties increase in the likelihood of democratization in both types, the effect is stronger in party regimes. One interpretation of this finding is that parties in non-military regimes have larger coalitions and deeper support networks than parties in military regimes.

\section{Authoritarian leaders' post-exit fate}

In this section we examine how authoritarian parties and legislatures affect the post-exit fate of dictators. If the theory outlined above is correct, then parties in military and dominant party regimes should help protect the well-being of dictators themselves after an exit from power, while these institutions should have little effect on the welfare of dictators exiting from personalist regimes. We use a data set of authoritarian leaders that codes both the year of their exit from power and the post-exit fate of the leader. ${ }^{71}$ The data is almost identical to the commonly used Archigos data, except that the unit of observation is the country year and thus only codes one leader per country per year. ${ }^{72}$ The fate variable can take four values: the leader (1) remains in the country with impunity; (2) exile or lives abroad; (3) arrested, in jail, or on trial; or (4) assassinated or murdered.

We analyze this data in two ways. First, we look only at authoritarian leaders who have exited power; thus we have one observation for a leader-exit. Using a multinomial logit model and controlling for level of development, economic growth, and civil war, we estimate how parties and legislatures affect the probabilities of the bad outcomes (exile, arrest, death) relative to the category of "remains in the country with impunity." Civil wars might be expected to increase the likelihood of leader assassination or murder; and economic growth during the leader transition often influences the bargaining capacity of the

outgoing leader. ${ }^{74}$ Second, we analyze the exit data using survival analysis. Controlling for 
time dependence, economic growth, logged GDP per capita, civil war, and military regimes, we estimate how parties and legislatures affect different types of leader failure, where the leader failure types are the post-exit tenure categories (1-4). Here observations are leaderyears, and the base outcome is not exit/right-censored.

The results in the first column of Table 5 indicate that, conditional on having exited, parties in non-personalist regimes reduce the likelihood of all the bad outcomes (from the perspective of the dictator) relative to the best outcome (remain with impunity in the country). This result is consistent with the logic suggesting that parties protect the interests of authoritarian incumbents after they leave power. Legislatures in these regimes, however, have little effect on the type of exit, conditional on having exited. The results in the second column suggest that in personalist regimes, neither parties nor legislatures reduce the risk of bad types of exit. In short, these models indicate that, conditional on having exited, only parties in non-personalist regimes protect exiting dictators against particularly nasty outcomes. 
Table 5: Authoritarian parties and leaders' post-exit fate

\begin{tabular}{|c|c|c|c|c|}
\hline \multirow{2}{*}{$\begin{array}{l}\text { Base outcome } \\
\text { Impunity, remain in } \\
\text { country }\end{array}$} & \multicolumn{2}{|c|}{$\begin{array}{c}\text { Impunity } \\
\text { (Conditional on having exited, 1-2) }\end{array}$} & \multicolumn{2}{|c|}{$\begin{array}{l}\text { Not exited/censored } \\
(\text { Duration models, 3-4) }\end{array}$} \\
\hline & Non-personal & $\underline{\text { Personal }}$ & $\underline{\text { Non-personal }}$ & $\underline{\text { Personal }}$ \\
\hline Parties & & & $\begin{array}{c}0.701 * * \\
(0.18)\end{array}$ & $\begin{array}{l}0.179 \\
(0.33)\end{array}$ \\
\hline Legislature & & & $\begin{array}{l}0.053 \\
(0.09)\end{array}$ & $\begin{array}{l}0.209 \\
(0.17)\end{array}$ \\
\hline Civil war & & & $\begin{array}{l}-0.202 \\
(0.38)\end{array}$ & $\begin{array}{l}-0.274 \\
(0.81)\end{array}$ \\
\hline $\ln (\mathrm{GDPpc})$ & & & $\begin{array}{l}0.248^{*} \\
(0.12)\end{array}$ & $\begin{array}{l}-0.154 \\
(0.41)\end{array}$ \\
\hline Growth & & & $\begin{array}{l}-1.097 \\
(1.94)\end{array}$ & $\begin{array}{l}-0.808 \\
(4.68)\end{array}$ \\
\hline Military & & & $\begin{array}{l}1.350^{* *} \\
(0.28)\end{array}$ & \\
\hline \multicolumn{5}{|l|}{ Exile abroad } \\
\hline Parties & $\begin{array}{l}0.307 \\
(0.34)\end{array}$ & $\begin{array}{l}0.324 \\
(0.43)\end{array}$ & $\begin{array}{c}1.128 * * \\
(0.30)\end{array}$ & $\begin{array}{l}0.185 \\
(0.28)\end{array}$ \\
\hline Legislature & $\begin{array}{l}-0.134 \\
(0.14)\end{array}$ & $\begin{array}{l}0.083 \\
(0.25)\end{array}$ & $\begin{array}{c}-0.350^{*} \\
(0.17)\end{array}$ & $\begin{array}{l}0.042 \\
(0.18)\end{array}$ \\
\hline Civil war & $\begin{array}{l}0.198 \\
(0.66)\end{array}$ & $\begin{array}{l}1.294 \\
(0.90)\end{array}$ & $\begin{array}{l}-0.000 \\
(0.55)\end{array}$ & $\begin{array}{c}1.791 * * \\
(0.52)\end{array}$ \\
\hline $\ln (\mathrm{GDPpc})$ & $\begin{array}{l}-0.559^{*} \\
(0.24)\end{array}$ & $\begin{array}{l}-0.277 \\
(0.53)\end{array}$ & $\begin{array}{l}-0.274 \\
(0.18)\end{array}$ & $\begin{array}{l}0.061 \\
(0.35)\end{array}$ \\
\hline Growth & $\begin{array}{l}3.336 \\
(4.24)\end{array}$ & $\begin{array}{l}9.202 \\
(7.80)\end{array}$ & $\begin{array}{l}1.290 \\
(2.96)\end{array}$ & $\begin{array}{l}6.316 \\
(4.37)\end{array}$ \\
\hline Military & & & $\begin{array}{l}0.319 \\
(0.44)\end{array}$ & \\
\hline \multicolumn{5}{|l|}{ Jailed, arrested } \\
\hline Parties & $\begin{array}{c}-1.060 * * \\
(0.39)\end{array}$ & $\begin{array}{l}-0.791 \\
(0.62)\end{array}$ & $\begin{array}{l}-0.271 \\
(0.33)\end{array}$ & $\begin{array}{c}-1.105+ \\
(0.59)\end{array}$ \\
\hline Legislature & $\begin{array}{l}-0.138 \\
(0.15)\end{array}$ & $\begin{array}{l}0.164 \\
(0.32)\end{array}$ & $\begin{array}{l}-0.154 \\
(0.19)\end{array}$ & $\begin{array}{l}0.143 \\
(0.28)\end{array}$ \\
\hline Civil war & $\begin{array}{l}0.469 \\
(0.70)\end{array}$ & $\begin{array}{l}1.225 \\
(1.01)\end{array}$ & $\begin{array}{l}0.448 \\
(0.58)\end{array}$ & $\begin{array}{l}1.630^{*} \\
(0.71)\end{array}$ \\
\hline $\ln ($ GDPpc $)$ & $\begin{array}{l}0.228 \\
(0.28)\end{array}$ & $\begin{array}{l}-0.740 \\
(0.74)\end{array}$ & $\begin{array}{l}0.286 \\
(0.24)\end{array}$ & $\begin{array}{l}-0.663 \\
(0.57)\end{array}$ \\
\hline Growth & $\begin{array}{l}-5.323 \\
(5.09)\end{array}$ & $\begin{array}{l}0.459 \\
(8.99)\end{array}$ & $\begin{array}{l}-2.403 \\
(3.40)\end{array}$ & $\begin{array}{l}3.218 \\
(5.74)\end{array}$ \\
\hline Military & & & $\begin{array}{l}0.849 \\
(0.52)\end{array}$ & \\
\hline Assassinated, executed & & & & \\
\hline Parties & $\begin{array}{c}-3.041^{* *} \\
(0.85)\end{array}$ & $\begin{array}{l}0.428 \\
(0.54)\end{array}$ & $\begin{array}{c}-2.018^{*} \\
(0.80)\end{array}$ & $\begin{array}{l}0.437 \\
(0.41)\end{array}$ \\
\hline Legislature & $\begin{array}{r}-0.278 \\
(0.27)\end{array}$ & $\begin{array}{l}-0.196 \\
(0.32)\end{array}$ & $\begin{array}{l}-0.450 \\
(0.41)\end{array}$ & $\begin{array}{l}0.206 \\
(0.25)\end{array}$ \\
\hline Civil war & $\begin{array}{l}1.552 \\
(0.97)\end{array}$ & $\begin{array}{l}0.609 \\
(1.08)\end{array}$ & $\begin{array}{l}1.241 \\
(0.77)\end{array}$ & $\begin{array}{l}0.285 \\
(0.82)\end{array}$ \\
\hline $\ln (\mathrm{GDPpc})$ & $\begin{array}{l}0.467 \\
(0.48)\end{array}$ & $\begin{array}{l}-1.070 \\
(0.71)\end{array}$ & $\begin{array}{l}0.222 \\
(0.38)\end{array}$ & $\begin{array}{c}-1.428 * \\
(0.60)\end{array}$ \\
\hline Growth & $\begin{array}{l}-6.862 \\
(6.97)\end{array}$ & $\begin{array}{l}-1.751 \\
(9.37)\end{array}$ & $\begin{array}{l}-4.040 \\
(4.75)\end{array}$ & $\begin{array}{l}-4.297 \\
(5.58)\end{array}$ \\
\hline Military & & & $\begin{array}{l}1.224 \\
(0.83) \\
\end{array}$ & \\
\hline Log-likelihood & -219.4 & -82.2 & -892.5 & -295.6 \\
\hline $\mathrm{N}$ & 218 & 67 & 2237 & 867 \\
\hline
\end{tabular}


The first two models only examine dictators who have exited power, which may bias the results because these models exclude dictators who remain in power or who died in office (censored dictators). So in the last two columns we run the similar specifications using survival analysis (with unreported controls for time dependence) with multiple failure outcomes. ${ }^{75}$ These results suggest that parties increase the likelihood of exiting power but remaining in the country with impunity and the likelihood of being exile, but decrease the likelihood of exit by death or assassination. Legislatures in general have no effect on different types of exit, except in one case, slightly decreasing the likelihood of exile. These findings are consistent with the expectation that parties in non-personalist regimes protect the interests of exiting dictators. In personalist regimes, parties reduce the likelihood of being arrested and jailed after exiting power, but increase the likelihood of death or assassination. Legislatures again have little effect on exit in personalist regimes. Overall these results, particularly the finding suggesting that parties decrease the likelihood of death after exit in non-personalist regimes but increase this probability in personalist regimes, are consistent with the argument that parties can protect elite interests, but only in nonpersonalist regimes.

\section{Discussion}

The results in this paper provide further evidence for the growing consensus that authoritarian institutions matter. ${ }^{76}$ The main contribution of the present study is to help us understand the channels through which authoritarian institutions affect authoritarian regime survival. By separating out the mechanisms through which parties and legislatures influence the payoffs for both authoritarian incumbents and potential regime opponents, and by 
modeling democratization as a separate failure outcome from transition to subsequent dictatorship, we have uncovered some revealing patterns. The finding that legislatures in non-personalist regimes reduce the likelihood of being replaced by a subsequent authoritarian regime is consistent with much of the literature which posits that institutionalization is stabilizing. Our interpretation of this finding is that legislatures in these regimes increase the credibility of promises made to potential regime opponents.

The finding that parties in non-personalist regimes can destabilise dictators by making democratization more likely stands at odds with some of the literature which argues that authoritarian parties stabilise dictators. ${ }^{7778}$ The logic underlying this finding, we suggest, reflects the fact that political parties, even when devised to quell threats from authoritarian rivals, can be strong enough to exert influence over the distribution of power in a subsequent democracy. This point echoes the reasoning Dahl suggests for why economic equality should make democracy more likely: higher equality means that the median voter in a democracy will be less likely to prefer redistribution from the rich to the poor, making the rich more amenable to democratization. ${ }^{79}$ The basic insight, which we argue is applicable to parties in non-personalist regimes, is that when the elite are less threatened by democratization, they are more likely to adopt it. Some of the most influential theories of comparative democratization in recent years make this intuition central to their explanation of democracy. ${ }^{80}$

The present paper expands on this notion by suggesting that party legacies can play a similar role of protecting elite interests in a subsequent democracy. The central interest of authoritarian elites may not simply be to protect themselves from taxation under democracy, particularly for military elites who may be more concerned about military budgets and avoiding prosecution for human rights violations. Political institutions are thus relevant 
when considering the wide range of interests outgoing authoritarian elites may have. This logic of exit guarantees invites a more careful analysis of other types of authoritarian political institutions that can exert influence over the distribution of power in a new democracy. While this paper has focused on legislatures and party systems, judicial institutions merit systematic examination as well. ${ }^{81}$

The argument for why parties can help protect the interests of outgoing elites in a post-transition democracy has further testable implications. In Table 1 we noted that some former dominant parties meet with considerable electoral success in new democracies. ${ }^{82} \mathrm{We}$ underscored this point in a crude way by showing how former parties performed in posttransition elections. However, some former regime elite start new parties that propel them to electoral success in post-transition democracies, as the 2004 and 2009 presidential victories for Susilo Bambang Yudhoyono in Indonesia illustrate. Yudhoyono was a high-ranking general in the Suharto regime that collapsed in 1998, but now leads the Democratic Party which defeated the former ruling party, Golkar, in the 2009 parliamentary elections. Thus the task of tracking the electoral success of former regime elite is more difficult than the tallies reported in Table 1. Future research might take up this question by exploring the relationship between political leaders (not simply parties) in a post-transition democracy and the former ruling elite. In addition, this argument suggests that parties should help protect the interests of former military rulers. This implication might be tested by examining how parties affect military budgets and the likelihood of human rights prosecution of former military leaders in post-transition democracies.

By distinguishing political institutions in personalist regimes from those in other types of regimes, this research also contributes to the small, but growing literature which utilises variation among different types of authoritarian regimes to help us understand 
phenomena as distinct as economic growth, investment, international conflict, civil conflict, and infant mortality. ${ }^{83}$ While students of comparative politics were the first to note and systematically disaggregate personalistic rule from other types of authoritarian polities, it has mostly been international relations scholars who have thought through how variation among different types of regimes might affect their theories. ${ }^{84}$ Other important questions in comparative political economy might be fruitfully explored by distinguishing personalist rule from other types of authoritarianism - for example, the literature on the human capital benefits of democratization, the trade consequences of democratization, or the resource curse.

We find empirical support for the argument that political parties can increase the likelihood of a democratic transition. Our interpretation of this evidence is that parties help guarantee the interests of autocratic elites - either in the form of greater access to power under a new democracy or by securing particular interests of the outgoing elite. This interpretation finds further support when we analyze how parties affect the likelihood of particularly bad post-tenure fates of authoritarian leaders. We attempt to delineate when the democratizing effects of parties outweigh the potential stabilizing affects by separating personalist regimes from non-personalist regimes. To do this, we simply used a dummy variable to capture the former. Future research will benefit from thinking more carefully about when party features that contribute to "exit guarantees" are stronger than the stabilizing factors of parties. In doing so, we might also unpack the specific features of personalist regimes, such as the size of the support coalition or the relationship between the leader and the party, that appear to make them distinct from other types of regimes. 


\section{Notes}

* The Pennsylvania State University and Universitat Pompeu Fabra. The authors thank Jennifer Gandhi, Barbara Geddes, Robert Fishman, James Honaker, Scott Mainwaring, Andreas Schedler, six anonymous reviewers, and participants at the conference, "Dictatorships: Their Governance and Social Consequences," at Princeton University (April 25-26, 2008) for helpful comments on previous drafts of this paper. All errors remain our own.

${ }^{1}$ Barbara Geddes, 'Authoritarian Breakdown: Empirical Test of a Game Theoretic Argument.' presented at the American Political Science Association's annual meeting (September 1999). Carles Boix, Democracy and Redistribution (Cambridge: Cambridge University Press, 2003). Benjamin Smith, 2005. 'Life of the Party: The Origins of Regime Breakdown and Persistence under Single-Party Rule', World Politics, 57 (1997), 421451. Jennifer Gandhi and Adam Przeworski, 'Authoritarian Institutions and the Survival of Autocrats', Comparative Political Studies, 40 (2007), 1279-1301. Jason Brownlee, Authoritarianism in the Age of Democratization (New York: Cambridge University Press, 2007). Jennifer Gandhi, Political Institutions Under Dictatorship (New York: Cambridge University Press, 2008). Barbara Geddes, 'Party Creation as an Autocratic Survival Strategy', presented at "Dictatorships: Their Governance and Social Consequences" Conference at Princeton University (May 2008). Beatrice Magaloni, 'Credible Power-Sharing and the Longevity of Authoritarian Rule', Comparative Political Studies, 41(2008), 715-741.

${ }^{2}$ Boix, Democracy and Redistribution; Daron Acemoglu and James Robinson, Economic Origins of Dictatorship and Democracy (New York: Cambridge University Press, 2006).

${ }^{3}$ Allan Meltzer and Scott Richard, 'A Rational Theory of the Size of Government', Journal of Political Economy 89 (1981), 914-27.

${ }^{4}$ Eric Nordlinger, Soldiers in Politics: Military Coups and Governments. (Englewood Cliffs, NJ: Prentice Hall, 1997).

5 Acemoglu and Robinson, Economic Origins of Democracy and Dictatorship. Boix, Democracy and Redistribution.

${ }^{6}$ Acemoglu and Robinson, Economic Origins of Democracy and Dictatorship. Boix, Democracy and Redistribution. Elisabeth Jean Wood, Forging Democracy from Below (Cambridge: Cambridge University 
Press, 2000).

${ }^{7}$ Gandhi and Przeworski, 'Authoritarian Institutions and the Survival of Autocrats.'

${ }^{8}$ Acemoglu and Robinson, Economic Origins of Democracy and Dictatorship.

${ }^{9}$ Carles Boix and Milan Svolik, 'The Foundations of Limited Authoritarian Government: Institutions and Power-sharing in Dictatorships', presented at "Dictatorships: Their Governance and Social Consequences" Conference at Princeton University (May 2008).

${ }^{10}$ Gandhi and Przeworski, 'Authoritarian Institutions and the Survival of Autocrats'. Magaloni, 'Credible Power-Sharing and the Longevity of Authoritarian Rule.'

${ }^{11}$ Ellen Lust-Okar, Structuring Conflict in the Arab World: Incumbents, Opponents and Institutions (New York: Cambridge University Press, 2005). Geddes, 'Party Creation as an Autocratic Survival Strategy.'

${ }^{12}$ Gary Cox and Mathew D. McCubbins, Legislative Leviathan (Berkeley: University of California Press, 1993). John Aldrich 1995, Why Parties? (Chicago: University of Chicago Press, 1995).

${ }^{13}$ Abel Escribà-Folch, 'The Political Economy of Growth and Accountability under Dictatorship' (CEACS, Instituto Juan March, 2007).

14 There is considerable variation in the electoral success of former authoritarian parties in democratic elections; but a full analysis of this question is beyond the scope of the present paper. However, see Anna Grzymala-Busse, Redeeming the Communist Past (Cambridge: Cambridge University Press, 2002).

${ }^{15}$ Terry Lynn Karl, 'Dilemmas of Democratization in Latin America', Comparative Politics 23(1990), 1-21. Josep Colomer, 'Transitions by Agreement: Modeling the Spanish Way', American Political Science Review 85(1991), 1283-1302.

${ }^{16}$ Robert H Dix, 'The Breakdown of Authoritarian Regimes', The Western Political Quarterly 35(1982), 554573.

${ }^{17}$ Juan Linz and H.E. Chehabi, Sultanistic Regimes (Baltimore: John Hopkins University Press, 1998). Ronald Wintrobe, The Political Economy of Dictatorship (Cambridge: Cambridge University Press, 1998). Geddes, 'Authoritarian Breakdown: Empirical Test of a Game Theoretic Argument.'

18 These typological distinctions are not simply another way of coding institutional variables such as the number of parties or legislatures. As Table 2 (see below) demonstrates, all institutional configurations are found in all types of regimes. 
${ }^{19}$ Robert Jackson and Carl Rosberg, Personal Rule in Black Africa (Berkeley: University of California Press, 1982). Michael Bratton and Nicolas van de Walle, 'Patrimonial Regimes and Political Transitions in Africa', World Politics 46(1994), 453-89. Linz and Chehabi, Sultanistic Regimes. Wintrobe, The Political Economy of Dictatorship. Geddes, 'Authoritarian Breakdown: Empirical Test of a Game Theoretic Argument.'

${ }^{20}$ Geddes, 'Authoritarian Breakdown', Bratton and Nicolas van de Walle, 'Patrimonial Regimes and Political Transitions in Africa'. Mark Peceny, Caroline Beer, and Shannon Sanchez-Terry, 'Dictatorial Peace?', American Political Science Review 96(2002), 15-26. Dan Reiter and Allan Stam, 'Identifying the Cultprit: Democracy, Dictatorship, and Dispute Initiation', American Political Science Review 97(2003), 333-337.

${ }^{21}$ Reiter and Stam, 'Identifying the Cultprit: Democracy, Dictatorship, and Dispute Initiation.'

${ }^{22}$ Barbara Geddes, Paradigms and Sand Castles (Ann Arbor: University of Michigan Press, 2003).

${ }^{23}$ Bratton and Nicolas van de Walle, 'Patrimonial Regimes and Political Transitions in Africa.'

${ }^{24}$ Joseph Wright, 'Do Authoritarian Institutions Constrain? How Legislatures Impact Economic Growth and Investment', American Journal of Political Science 52(2008), 322-43.

${ }^{25}$ Lust-Okar, Structuring Conflict in the Arab World; Wright, 'Do Authoritarian Institutions Constrain?'

${ }^{26}$ Howard Wiarda, Dictatorship and Development: The Methods of Control in Trujillo's Government. (Gainesville: University of Florida Press, 1968).

${ }^{27}$ Wiarda, Dictatorship and Development.

${ }^{28}$ Samuel Decalo, The Stable Minority: Civilian Rule in Africa, 1960-1990 (Gainesville and London: Florida Academic Press, 1998), p. 68.

${ }^{29} \mathrm{We}$ are grateful to an anonymous reviewer for pointing this out to us.

${ }^{30}$ Party-based regimes without legislatures include: Algeria 1965-1976, Bolivia 1953-1954, Burundi 19681987, Iraq 1969-1979, Laos 1985-1990, Lesotho 1970-1986, Panama 1968-77, Rwanda 1974-1988. A quick comparison of these regimes with the mass party organization of the PRI in Mexico or the CCM in Tanzania suggests that the latter parties (with legislatures) had much more extensive distribution networks and voter mobilization reach.

${ }^{31}$ As an example of the "winner" category, recall that in Mexico while the PRI candidate lost to the PAN candidate in the presidential election in 2000 and placed third in 2006, the PRI won the largest share of votes in the lower house in 2003. See the Appendix for details on the post-transition electoral results used to code 
these parties (A-12).

${ }^{32}$ Wendy Hunter, Eroding Military Influence in Brazil (Chapel Hill: University of North Carolina Press, 1997), p. 103.

${ }^{33}$ Many ARENA legislators left the party after 1985, leading to the demise of ARENA, but these legislators often found homes in other parties. See Frances Hagopian, 'Democracy by Undemocratic Means? Elites, Political Pacts, and Regime Transition in Contemporary Brazil', Comparative Political Studies 23(1990), $147-70$.

${ }^{34}$ Nordlinger, Soldiers in Politics, Geddes, 'Authoritarian Breakdown.'

${ }^{35}$ Karl, 'Dilemmas of Democratization', Colomer, 'Transitions by Agreement.'

${ }^{36}$ Karl codes Colombia (1958), Chile (1998), Uruguay (1984), and Venezuela (1958), as pacted transitions to democracy. However, the military also bargained with political party elites over military prerogatives in El Salvador (1982), Guatemala (1985) and Honduras (1982). See Phillip Williams and Knut Walter, Militarization and Demilitarization in El Salvador's Transition to Democracy (Pittsburgh: University of Pittsburgh Press, 1997) and Jennifer Schirmer, The Guatemalan Military Project. A Violence Called Democracy (Philadelphia: University of Pennsylvania Press, 1998).

${ }^{37}$ The New York Times reported that a pre-election survey predicted Larrazábal to defeat both the Acción Democrática (Rómulo Betancourt) and COPEI (Rafael Caldera) candidates. The poll and military were wrong; Betancourt won with 47 per cent of the vote, ending military rule. See Harry Kantor, 'The Development of Accion Democratica de Venezuela', The Journal of Inter-American Studies, 1(1959), 237255, p. 238.

${ }^{38}$ Croissant argues that Roh Tae-woo "personally guaranteed the protection of the military's interests, values, and political status." See Aurel Croissant, 'Riding the Tiger: Civilian Control and the Military in Democratizing Korea', Armed Forces \& Society 30(2004), 357-381, p. 371.

${ }^{39}$ Daniel King, 'The Thai Parliamentary Elections of 1992', Asian Survey 32(1992), 1109-1123, Daniel King and Jim LoGerfo, 'Thailand: Toward Democratic Stability', Journal of Democracy 7(1996), 102-117.

${ }^{40}$ Michael Mezey, 'The 1971 Coup in Thailand: Understanding Why the Legislature Fails', Asian Survey 13(1973), 306-317.

${ }^{41}$ Robert Zimmerman, 'Student Revolution in Thailand: The End of the Thai Bureaucratic Polity?', Asian 
Survey 14(1974), 509-529.

${ }^{42}$ Geddes, 'Authoritarian Breakdown', Geddes, Paradigms and Sand Castles, Wright, 'Do Authoritarian Institutions Constrain?'

${ }^{43}$ Hein Goemans, Kristian Skrede Gleditsch, and Giacomo Chiozza, 'Introducing Archigos: A Data Set of Political Leaders', Journal of Peace Research 46(2009), 269-283.

${ }^{44}$ Gandhi, Political Institutions Under Dictatorship. Because these data are coded as of December 31st each year, we recode these variables with the previous year's observation for years in which there is a transition. Without these changes to the institutions variables, the coding would be endogenous by construction.

${ }^{45}$ This variable for parties measures defacto parties which are parties that exist outside the ruling front. This variable does not code whether the parties have seats in the legislature.

${ }^{46}$ Williams and Walter, Militarization and Demilitarization

${ }^{47}$ Nathaniel Beck, Jonathan Katz, and Richard Tuck, 'Taking Time Seriously: Time-Series-Cross-Section Analysis with a Binary Dependent Variable', American Journal of Political Science 42(1998), 1260-1288. David Carter and Curt Signorino, 'Back to the Future: Modeling Time Dependence in Binary Data', Political Analysis 18(2010), 271-292. F-tests suggest that duration $^{3}$ does not belong in the transitions equations.

48 Adam Przeworski, Michael Alvarez, Jose Antonio Cheibub, and Fernando Limongi, Democracy and Development (New York: Cambridge University Press, 2000). Carles Boix and Susan Stokes, 'Endogenous Democratization', World Politics 55(2003), 517-549.

${ }^{49}$ Geddes, 'Authoritarian Breakdown', Brownlee, Authoritarianism in the Age of Democratization.

${ }^{50}$ Felipe Agüero, 'Legacies of Transitions: Institutionalization, the Military, and Democracy in South America, Mershon International Studies Review 424(1991), 383-404, David Pion-Berlin, 'Between Confrontation and Accommodation: Military and Government Policy in Democratic Argentina', Journal of Latin American Studies 23(1991), 543-571.

${ }^{51}$ Michael Schatzberg, 'Beyond Mobutu: Kabila and the Congo', Journal of Democracy 8(1997), 70-84.

${ }^{52}$ G. S. Maddala, Limited Dependent and Qualitative Variables in Econometrics (Cambridge: Cambridge University Press, 2003).

${ }^{53}$ Maddala, Limited Dependent and Qualitative Variables, p.244-245

${ }^{54}$ We estimated the parties equation in (3) using both ordered probit and OLS with the same set of explanatory 
variables $\left(X_{1}, X_{2}\right)$. The instruments produced by these two estimation methods are nearly perfectly collinear (though with different scales; the in-sample correlation coefficient is 0.997 ). This means that the cut points in the ordered model are capturing roughly the same amount of (linear) latent space. This should give us some confidence that using OLS instead of an ordered model in (3) will produce similar results. We then estimated a full maximum likelihood model of equations (1)-(4) in which Parties is estimated with OLS and Democ with a probit. See Omar Keshk, 'CDSIMEQ: A program to implement two-stage probit least squares', The Stata Journal 3(2003), 157-167. This estimation corrects the standard errors according to the method suggested by Maddala (244-245). Next, we compared the standard errors from the two-step estimator (using OLS in (3)) and the full maximum likelihood estimator. We found that in each of the specifications the corrected standard errors were roughly two percent larger than the (uncorrected) standard errors from the two-step estimator. We then estimated the system using an ordered model for (1) and (3) in two-stages and adjusted the errors in (2). In the Democracy models 1-3 in Table 3, we inflated the errors by 2.0 per cent and deflated the errors in the Dictator models by 5.7 per cent (for the institutions variables). In models 4-6, the respective standard error corrections were: +4.5 per cent and -6.2 per cent. In models $7-9$, the respective standard errors corrections were: +3.3 per cent and -1.2 per cent.

${ }^{55}$ Islam is the share of the population that is Muslim, from Bruce Bueno de Mequita, Alastair Smith, Randolph Siverson, and James Morrow, Logic of Political Survival (Cambridge: MIT Press, 2003).with updates from the CIA World Factbook. Ethnic fractionalization is from James D. Fearon and David Laitin, 'Ethnicity, Insurgency, and Civil War', American Political Science Review 97(2003), 75-90. Both of these variables are time invariant.

${ }^{56} \log (G D P p c)$ and Growth are from Angus Maddison The World Economy: Historical Statistics (Paris: OECD, 2003) Growth is the lagged moving average of growth in the previous two years. Cold War is coded as one for all years between 1946 and 1989.

${ }^{57}$ Harvey Starr and Christina Lindborg, 'Democratic Dominoes Revisited: The Hazards of Governmental Transitions, 1974-1996', Journal of Conflict Resolution 47(2003), 490-519. Daniel Brinks and Michael Coppedge, 'Diffusion Is No Illusion: Neighbour Emulation in the Third Wave of Democracy', Comparative Political Studies 39(2660), 463-489.

${ }^{58}$ Geddes, 'Authoritarian Breakdown.’ 
${ }^{59}$ If the control for Military regime is excluded from the specification, legislatures decrease the likelihood of democratization, a finding consistent with Hypothesis 2.

${ }^{60}$ Predicted probabilities calculated from models 6 and 9 in Table 3, respectively. We use CLARIFY and set Cold War to zero with all other variables set to their mean or median values. For CLARIFY, see Michael Tomz, Jason Wittenberg and Gary King, 'Making the Most of Statistical Analyses: Improving Interpretation and Presentation', American Journal of Political Science 44(2000), 347-61. For each regime type, we set the duration variables to the in-sample mean value for each regime type. For military regimes, this value is 7 , for personalist regimes 12, and for party regimes 20. The instrument for parties (Parties) is a continuous variable, so we take the median Parties from the distribution of Parties 's that lies below the first cutpoint (zero parties); the median between the cut-point (one party); and the median Parties from the distribution of Parties 's that lies above the second cut-point (two parties). For Legis $\hat{l}$ ature, we use the median Legisilature for the subset of Legisilature's that lie below the mean predicted value as 'no legislature' and the median Legisilature for the subset of Legisilature's that above below the mean predicted value as 'legislature'. These latter values are close to the 25 per centtile and the 75 per centtile of the distribution of Legisilature's.

${ }^{61}$ Lust-Okar, Structuring Conflict in the Arab World, Magaloni, 'Credible Power-Sharing and the Longevity of Authoritarian Rule.'

${ }^{62}$ Geddes, 'Authoritarian Breakdown.'

${ }^{63}$ John Londregan and Keith Poole, 'Poverty, The Coup Trap, and the Seizure of Executive Power', World Politics 42(1990), 151-183.

${ }^{64}$ Mark Gasiorowski, 'Economic Crisis and Political Regime Change: An Event History Analysis', American Political Science Review 89(1995), 882-97.

${ }^{65}$ Geddes, 'Authoritarian Breakdown.’

${ }^{66}$ We also checked these results with a Heckman selection model where the first stage models selection into one of three categories: no parties; one-party; multiple-parties. The results from this analysis suggest that multiple-parties increase the likelihood of democratization. Among non-personalist regimes, the likelihood of democratization is 0.6 per cent, increasing to 0.8 per cent with one party, and increasing again to 3.1 per cent 
with multiple parties.

${ }^{67}$ In a random effects specification, though, these coefficients are statistically significant at the 0.10 level.

${ }^{68} \mathrm{We}$ did not estimate separate samples for military and party-based regimes because nearly all party regimes have a legislature.

${ }^{69}$ There are many fewer observations for military regimes than for dominant party regimes, reflected in the larger standard error estimate for Parties is military regimes.

${ }^{70}$ Gandhi and Przeworski, 'Authoritarian Institutions and the Survival of Autocrats', Abel Escribà-Folch, 'El Destino de los Dictadores tras el Poder. ¿Quién y Cómo Puede Castigarlos?', Revista de Estudios Politicos 140(2008), 105-133.

${ }^{71}$ Concretely, this data is coded as the Effective Head of Government: (1) presidents in presidential democracies; (2) prime ministers in parliamentary and mixed democracies, except in the cases of Djohar in Comoros and Preval in Haiti; (3) general-secretaries of the communist party in communist dictatorships, except in the case of Deng Xiaoping in China; (4) kings, presidents, and de facto rulers in non-communist dictatorships, except in the cases of Singapore, Malaysia, Cambodia, Laos, and Myanmar where the effective head is sometimes the prime minister; and (5) military or other figure when sources indicate nominal head is puppet figure.

${ }^{72}$ Goemans, Gleditsch, and Chiozza, 'Introducing Archigos: A Data Set of Political Leaders.'

${ }^{73}$ The Archigos data is episode data, with one observation per leader per country. The Archigos variable Post Tenure Fate indicates the fate of the leader in the period up to one year after the leader lost power: $0(\mathrm{OK}), 1$ (Exile), 2 (Imprisonment, including house arrent), or 3 (Death).

${ }^{74}$ Stephen Haggard and Kaufman, Political Economy of Democratic Transitions (Princeton: Princeton University Press, 1995).

${ }^{75}$ The results in columns 5 and 6 remain if we exclude those regimes that have regularised leadership turnover: Brazil (1964-1985), El Salvador (1948-1982), Mexico (1929-2000), Uruguay (1973-1984), and Tanzania (1986-2002/censored).

${ }^{76}$ Geddes, 'Authoritarian Breakdown', Boix, Democracy and Redistribution, Smith, 'Life of the Party', Beatric Magaloni, Voting for Autocracy: Hegeomonic Party Survival and Its Demise in Mexico, (New York: Cambridge University Press, 2006), Gandhi and Przeworski, 'Authoritarian Institutions and the Survival of 
Autocrats', Brownlee, Authoritarianism in the Age of Democratization Gandhi, Political Institutions Under Dictatorship, Magaloni, 'Credible Power-Sharing and the Longevity of Authoritarian Rule', Wright, 'Do Authoritarian Institutions Constrain?'

${ }^{77}$ Gandhi and Przeworski, 'Authoritarian Institutions and the Survival of Autocrats', Magaloni, 'Credible Power-Sharing and the Longevity of Authoritarian Rule', Geddes, 'Party Creation as an Autocratic Survival Strategy.'

${ }^{78}$ For a view which parallels ours, see Gary Cox, 'Authoritarian elections and leadership succession, 19752000’ manuscript. UCSD.

${ }^{79}$ Robert Dahl, 'Polyarchy' (New Haven: Yale University Press, 1971).

${ }^{80}$ Acemoglu and Robinson, Economic Origins of Democracy and Dictatorship. Boix, Democracy and Redistribution.

${ }^{81}$ See, for example, Tamir Moustafa, The Struggle for Constitutional Power: Law, Politics, and Economic Development in Egypt (New York: Cambridge University Press, 2007).

${ }^{82}$ Most of the sub-Saharan Africa dominant party regimes in Table 1 have not fared well in the post-transition period. However, some former authoritarian parties in personalist regimes in this region have met with some electoral success. For example, the NDC in Ghana finished a strong 2nd in 2004 and the MPC in Malawi finished a strong 2nd in 1999 and won in 2004. This underscores the need to measure the relationship between the leader and the party more precisely than a dummy variable for Personalist regimes.

${ }^{83}$ Peceny, Beer, and Sanchez-Terry, 'Dictatorial Peace?', Reiter and Stam, 'Identifying the Cultprit' Peceny \& Sanchez-Terry 2002, Reiter \& Stam 2003, Jessica Weeks, 'Autocratic Audience Costs: Regime Type and Signaling Resolve', International Organization 62(2008), 35-64, Wright, 'Do Authoritarian Institutions Constrain?', Hanne Fjelde, 'Generals, Dictators, and Kings: Authoritarian Regimes and Civil Conflict, 19732004', Conflict Management and Peace Science 27(2010), 195-218, Michael Albertrus, 'Political Regimes and Poverty Reduction, 1950-2002', manuscript, Stanford University.

${ }^{84}$ Jackson and Rosberg, Personal Rule in Black Africa, Bratton and van de Walle, 'Patrimonial Regimes and Political Transitions in Africa', Geddes, 'Authoritarian Breakdown.' 